\title{
The Case Against Perfection: Ethics in the Age of Genetic Engineering
}

By Michael J. Sandel. Published 2007 by Harvard University Press, Cambridge, MA. (176 pp., \$18.95).

Reviewed by William J. Morgan, Department of Occupational Science, University of Southern California, Los Angeles, CA.

In this slim, elegantly written, and persuasively argued book, Michael Sandel asks whether there is anything morally untoward about trying to make ourselves "better than well" through genetic engineering. Sport is one of his central targets in this regard but certainly not the only one. For Sandel is as interested in whether the bioengineering of humans will corrupt sporting ventures as he is in whether it will corrupt medicine, parenting, or countless other human endeavors that might be morally compromised by technological interventions of this magnitude. My review, of course, will concentrate mainly on what he has to say about genetic enhancement in sports, which isn't as narrow a take on Sandel's wide-ranging examination of the ethics of genetic engineering as it might at first seem because it has obvious implications for any perfectionist practice in which excellence of one kind or another is the principal aim.

What makes Sandel's book such a compelling read, aside from its powerful prose, is not just its seductive topic-after all, what could be more tantalizing than the chance to remake ourselves genetically? — but the novel means by which it proposes to guide us morally through this technological thicket. For he lets it be known early on that he won't be dipping into the standard liberal vocabulary most ethical theorists consult when trying to figure out what is the right thing to do in a particular context. That means that appeals to such moral commonplaces as autonomy, fairness, and individual rights will not be found in his analysis, not because of any anti-liberal bias on his part, but because the topic of genetic engineering itself rules out, or so he claims, any such appeals.

That said, his ethical approach to genetic enhancement is not entirely novel even if the conclusions he draws are. For he begins his inquiry in much the same way as most contemporary ethical thinkers do, by probing our intuitions about this whole genetic enterprise. He thinks we have few other choices in this regard because scientific breakthroughs such as gene therapy almost always outpace our moral understanding, which gives rise to a kind of moral vertigo that renders us mostly inarticulate about how to think about them. That proves true of genetic engineering in spades, because we are left wondering whether the moral unease it engenders is merely a superstition that we need to shake off, or a deep ethical problem we need to resolve. Of course, because Sandel chose to write a book about the subject, it is clear he thinks it is a dilemma we need to unravel rather than a superstition we need to slough off. 
But if the genetic enhancement of athletes is a genuine moral problem, then what, exactly, is the problem? As far as Sandel is concerned, it has nothing to do with issues of safety or fairness. It has nothing to do with safety as a matter of stipulation, given that Sandel wants to know how we should morally think about the bioengineering of athletes on the presumption that it can be done safely. It has nothing to do with fairness for a different reason, namely, concerns about the fairness of genetic enhancement curiously ignore the blatant unfairness of natural inequalities. I say curiously because the inequalities in human capacities that genetic engineering might cause are no less morally worrisome than those already caused by the genetic lottery, which suggests that those who question the fairness of the former but not the latter are not only being hypocritical, but, wittingly or unwittingly, are signaling that their moral distress regarding genetic enhancement probably has to do with some other as yet unarticulated reason. What is more, argues Sandel, the whole question of fair access to such technological procedures is question begging, because the important question here is not access but rather the moral status of the aspiration itself.

Sandel's claim that the moral concerns of gene doping have to do with the aspiration itself suggests that it is the effect such interventions have on our agency, and how that agency gets played out in different spheres such as sports, that is the moral crux of the problem. However, Sandel won't be arguing that bioengineering athletes diminishes or otherwise undermines their agency thereby making it impossible to attribute whatever they achieve to their own doing. He won't be arguing such because he believes it has the opposite effect of expanding our agency beyond all reasonable bounds, of turning us, in effect, into super agents. As he sees it then, what is wrong with gene doping is not that we can no longer hold athletes responsible for their actions because it betrays a mechanistic understanding of human agency that is at odds with human freedom, but that it represents a "Promethean" aspiration to change our very human makeup to suit our every purpose. It is thus not "the drift to mechanism" but rather "the drive to mastery" that should give us moral pause about genetic engineering because it erodes our appreciation of the "gifted" character of human capacities and achievements.

To say that efforts to genetically enhance athletic performance undermine the gifted character of human life is to say that they depreciate a central feature of what it means to be a human being, namely, that our talents and achievements are not "wholly our own doing, nor even fully ours." This is, to say the least, a provocative argument, and, as far as I can tell, an entirely novel one, at least in the bioethics and philosophy of sport literature. So in making it, Sandel is breaking new argumentative ground that presents a bold ethical challenge to the distinctively technological idea that if something can be done it should be done. The idea, therefore, that human beings and the activities they choose to engage in can be used however we may desire or devise to use them is one, Sandel insists, that we better give up on, and the sooner the better if we hope to keep social practices like sports on an even ethical keel. For unless we are able to constrain ethically the drive to mastery that technological societies like our own tout as the key to our future success, we will become unrecognizable to ourselves as ethical beings, and, consequently, impervious to ethical claims made upon us.

Part of the appeal of Sandel's argument, aside from its originality, is that it fits so well the technological tenor of our times. And part of its appeal to sport 
philosophers is that it fits so well the central features of sport practices. For perfectionist endeavors like sports, according to Sandel, are based on two important but distinct ideals. The first ideal is the notion of striving, the idea that an important part of what it means to be an athlete, not to mention a human being, is that we constantly push ourselves to new heights, that we not rest on our past laurels but try to improve upon our previous efforts., Sandel is quick to point out, however, that there is more to sport than striving to be better, than working harder, and that more has to do with excellence and the indispensable role talent plays in its accomplishment. That is why athletic prizes are not handed out to those who have trained the hardest, but only to those who have the requisite talent that allows them to profit from strenuous training and achieve something truly extraordinary. If we leave either one of these athletic ideals unaccounted for, or if we play up one and play down the other, we will have failed to understand what the point of sports is. For just as sports are never simply a celebration of hard work, the aim is rather to outperform rather than outwork everyone else, they are never simply a celebration of talent. Merely showing up won't cut it - which is why athletes who do little more than this can expect instant derision rather than enduring acclaim.

It is easy to see from Sandel's account of the dual character of sports why he thinks genetic engineering corrupts them. For what is wrong with such genetic interventions is that it places too heavy an emphasis on the striving dimension of sports at the expense of their talent dimension. That is to say, it degrades sports by violating their gifted character, by disregarding that sport is "a human activity that honors the cultivation and display of natural talents" (p. 29). Sandel concedes, however, that it is not always easy to draw a line between things that "cultivate" and things that "corrupt" sports. But he thinks we can draw that line in a clear enough fashion so long as we remain mindful that whatever due is given to the striving feature of sport cannot compromise its reliance on natural gifts and vice versa, which is why he thinks training and protein shakes pass moral muster and genetic engineering manifestly does not. So what is wrong with gene doping, to reiterate, is not that it overrides effort and striving and diminishes our responsibility for our actions, but that it does just the opposite: it overrides our human capacities and makes us responsible for everything. And Sandel does mean responsible for everything as his following remarks attest, "Today when a basketball player misses a rebound, his coach can blame him for being out of position. Tomorrow the coach can blame him for being short" (p. 87).

As I said at the outset, Sandel's argument is a compelling and entirely original one but, alas, not a wholly persuasive one. For some especially acute criticisms in this regard, I would direct the interested reader to the articles published in The American Journal of Bioethics, Volume 5, Issue 3, 2005, all of which address Sandel's essay, which appeared in the Atlantic Monthly ("The Case Against Perfection,'Volume 293, Issue 3, 2004, pp. 51-62), and which informed the main argument of his book. In closing, however, I would like to consider briefly two critical problems I see with his argument.

The first problem concerns his account of human nature and of the talents, or gifts, so central to sports and their ilk. In the critical literature much has been made of the apparent fact that Sandel's notion of giftedness is essentially a religious notion that has no relevance to our secular age. The idea is that Sandel's claim that genetic enhancement is morally blameworthy only makes sense in a religious context in 
which one can justly be accused of playing God, of misconstruing one's place in the divine scheme of things. But in a secular age like our own, the argument is that such accusations fall flat precisely because modern human agents have selfconsciously taken it upon themselves to assume direct responsibility for their own lives, which explains Dworkin's indignant rejoinder, "If playing God means struggling to improve our species, . . . then the first principle of ethical individualism commands that struggle" (pp. 76-7). But I think that Sandel can easily escape such criticism because giftedness can be given a quite intelligible secular interpretation, in which it means nothing more than an appreciation of our talents.

What does seem problematic about even this secular reading of giftedness, however, is that it is not at all clear in what way genetic engineering undermines it. On the contrary, I would venture to claim that it is only when parents genetically design their children that the talents they pass on to them can be properly regarded as gifts. That is because the notion of a gift implies both a gift-giver and imparting something to someone else that is of positive value. Because ordinary procreation is a hit or miss affair, meaning that pregnancy is not always or even usually an outcome of sexual intercourse (ignoring for the moment contraception and the like), it is difficult to slot parents into the gift-giving category. What is more, because many traits children inherit from their parents are anything but positive, for example, a predisposition to heart disease, they can hardly be characterized as gifts. But if parents genetically design their children to be smart or athletic, then it seems reasonable to say both that they are gift-givers, that having a child with these specific features was the main intent and point of their use of this technology, and that these features possess the positive value that gifts are supposed to have. If so, then genetically designing elite athletes does not in any way compromise an appreciation of our talents, but enhances such appreciation in a way that natural procreation clearly does not, and cannot.

The second problem with Sandel's ethical account cuts directly to the heart of sports. As noted, Sandel's moral criticism of the bioengineering of athletes hinges on his conception of sports as a practice in which both striving and the display of natural talents are crucial to their integrity. In other words, his argument against genetic doping appeals to the "telos, or point" of sport practices So considered, genetic enhancement can be rightly said to corrupt sports because it compromises the important talents that they are supposed to contest, whereas things like running shoes can rightly be said to cultivate a sport like foot-racing because they remove an obstacle (stepping barefoot on a sharp object) to their successful pursuit.

But I don't find this line of reasoning convincing because it doesn't take into sufficient account how the point of practices like sports changes over time. For instance, Sandel mentions one of the central characters in Chariots of Fire who is morally ostracized for employing a professional coach to further his athletic ambitions, which violated the prevailing ethos of amateur sports at the time that mandated athletes train on their own or with their peers. Of course, this accusation of moral mischief today seems farfetched because the ethos of sport has changed rather dramatically. But it is not hard to show how his own moral case against bioengineering athletes gets into critical trouble if we update his above example.

Sandel notes how the reliance on natural talents in sports and other fields of endeavor is an embarrassment to meritocratic societies like our own, which place a very high premium on human striving and rewarding people for their hard work. 
In this same vein, I recall a student once coming up to me after a discussion of performance-enhancing drugs in class and exclaiming that he didn't see anything wrong in taking such substances to redress the natural inequalities of the genetic lottery. His declaration, which was quickly followed by an admission he actually used steroids, is a clear expression of the meritocratic faith Sandel refers to here, and prompts my following question to him. What would be morally amiss in reenvisaging sport, in true meritocratic fashion, as primarily a matter of striving for excellence in which, therefore, simply accepting one's talents as they come because they emanate from the genetic lottery is rejected in favor of genetic engineering? In other words, what is morally wrong in changing the way Sandel conceptualizes the interplay of these two features of sports? Striving could be allotted a more prominent role, and, accordingly, the appreciation of the talents necessary to be successful in sports is reserved not for the genetic wheel of fortune, where it seems somewhat misplaced, but for designing parents, or absent them, adult athletes who seek such enhancement for themselves.

Of course, there are always moral dangers in doing so, which Sandel has perceptively alerted us to in the case of genetically souped-up sports, but there are also moral dangers in stubbornly clinging to the status quo-in Sandel's case I would argue the main danger is elitism. And speaking of the status quo, I am not at all sure that the meritocratic version of sports I am proposing here is not itself the reigning, if partially hidden, conception of sports today, which would be one explanation as to why so many athletes still continue to use performance-enhancing drugs despite the harsh recriminations and alarming risks in doing so, and why they likely will not shy away from genetic technology once it is reasonably safe and available. In any event, I cannot find anything in Sandel's admirable argument, aside from his fierce assertion that we honor only natural talent and dishonor too much striving, that persuasively rules out such an egalitarian conception of sports.

These critical reservations notwithstanding, I remain convinced that Sandel's book is a most welcome addition to the literature and a must read for anyone who takes sports seriously, not to mention the coming genetic revolution.

\section{Confessions of a Spoilsport: My Life and Hard Times Fighting Sports Corruption at an Old Eastern University}

By William C. Dowling. Published in 2007 by The Pennsylvania State University Press, University Park, Pennsylvania (208 pp., \$23.95).

Reviewed by George H. Sage, Emeritus Professor, University of Northern Colorado, Greeley, $C O$.

The author, William C. Dowling, is a professor of English at Rutgers University; his teaching and research are in 18th century English literature, early American literature, and literary theory. He has an extensive scholarly publication record, a part of which includes 10 books. Although he has published newspaper op-ed pieces and journal articles about sport, Confessions of a Spoilsport is his first fulllength book about sport. 
Dowling earned his bachelor's degree at Dartmouth College and Ph.D. at Harvard. For him, high academic standards, scholarly allegiance, and intellectual values must be the central focus of colleges and universities. Scholarly and intellectually engaged faculty teaching bright and academically committed students should be the symbolic center of what higher education is about, in Dowling's view. He does grant that sports as an extracurricular activity, what he calls "participatory athletics"- meaning no athletic scholarships, no athletic dorms, no athletes-only tutoring, and no commercialization of the institution's sporting events-are appropriate in colleges and universities. He identifies NCAA Division III programs as an example.

Confessions of a Spoilsport is a withering assault on NCAA Division I-A sports. Dowling maintains they are alien, corruptive, and counterproductive influences at a university. As New York Times columnist Samuel Freedman (2007) said, Dowling is "convinced that the thunder of big-time athletics. . . [is] crumbling the ivory tower of academe" (p. B9). But Dowling's book is not just another depiction of the corruption, exploitation, hypocrisy, criminal behavior, unbridled pursuit of money, sliminess of boosters, and bogus admissions practices of big-time college sports that have been documented in other books. Indeed, one could easily fill a six-foot long book shelf with scathing accounts of big-time intercollegiate sports published in just the past 20 years.

This book does deal with all of those issues, but it is written from a personal perspective — much like an ethnographic study — of the author playing a leading role in the mobilization of students, faculty, and alumni who attempt to disassemble the machinery of big-time sports (NCAA Division I-A) at Rutgers University. He told a New York Times reporter: "We tried to take on the monster of commercialization sports" at Rutgers, "even if it swallowed us up and passed us out the other end" (Freedman, p. B9).

This Rutgers campaign had several of the main characteristics of social movements identified by sociologist Neil Smelser: structural conduciveness (the massive, nation-wide expansion of commercialized intercollegiate sports during the 1970s and 80s), participating events (Rutgers entry into big-time sports), structural strain (spread of a generalized sense of injustice or discontent) and organized mobilization of participants (organization of Rutgers 1,000-more on this later). This Rutgers social movement began in 1993 and remained an active, thriving group until 2002; during that time it attracted local, regional, and national attention.

Professor Dowling wastes no time in laying out his case against big-time NCAA Division I-A intercollegiate sports. In the first chapter he uses the events surrounding the murder of Baylor University basketball player Patrick Dennehy in the summer of 2003 as "a parable" for big-time college athletics, which he argues is filled with "corruption and hypocrisy and self-deception. Of pious claims and brutally cynical behavior. Of frightened faculty and powerful regents or trustees who see winning football and basketball teams as immeasurable more important than academic and intellectual values" (p. 1). To illustrate that the events at Baylor University are not an anomaly nor isolated, Dowling describes recent incidents of sexual assault and rape, grade changing and bogus credits, and financial fraud at the University of Georgia, Ohio State University, University of Minnesota, Virginia Tech, and the University of Colorado, all of which went on with the implicit or 
explicit knowledge of the coaches, other athletic personnel, faculty, boosters, and university administrators.

Having earned his Bachelor's and Ph.D. degrees at institutions with "participatory athletic" programs, Dowling received a shocking introduction to NCAA Division I-A athletics when he began teaching at the University of New Mexico in 1975. The UNM basketball team, coached by Norm Ellenberger, was a national contender, regularly filling its arena, "The Pit," with boisterous fans. He also discovered that in the midst of this big-time sports program, academic values and scholarly rigor at UNM left much to be desired-low student admission standards, low university expectations for students, few student opportunities for advanced courses or honors programs. For Dowling the link between the deplorable academic culture at UNM and the Division I-A sports program was apparent. So much state-wide attention was being lavished on the UNM basketball team that the best and brightest New Mexico high school students were going out of state, where intelligence and high academic achievement were valued. Dowling says the connection "between Norm Ellenberger's highly visible basketball program and the flight of New Mexico's best high school students to out-of-state-schools" seemed clear (p. 19). Furthermore, the best faculty members were departing for better universities as well.

During his tenure at UNM, Dowling witnessed one of the most infamous intercollegiate sport scandals of all time. It even had a name of its own: Lobogate. Needless to say, Dowling was appalled by the entire unsavory affair. It merely reaffirmed for him the ugliness of big-time college sports. At the earliest opportunity he resigned from UNM and subsequently acquired a faculty position in the Department of English at Rutgers University.

At Rutgers Dowling found an institution with a distinguished Ivy League-type of history. It was founded in 1766, before the United States existed, and it had a renowned academic reputation. Best of all, it had a president who encouraged the enrollment of intellectually talented students and the maintenance of high academic standards. Almost a perfect fit, Dowling thought, for his own intellectual proclivity and interests. I say "almost" because by the time that president died from a heart attack in 1989 he had begun to move Rutgers away from participatory sports and had launched a drive to enter the NCAA Division I-A Big East Conference. His successor, Francis L. Lawrence, supported the entry of Rutgers into the Big East Conference in 1991 and was a cheer-leading advocate of big-time athletics for Rutgers, even giving locker room pregame pep talks to the football team, according to Dowling.

Dowling asserts that with the march to Division I-A, the intellectual quality of students and the academic culture of Rutgers began to decline. Like New Mexico, the brightest students began to go out of state for their higher education, and those who remained were choosing other New Jersey universities over Rutgers. More alarming, Rutgers academic slide began to show up in the national rankings of universities. Gradually, some students, faculty, and alumni began to perceive the connection between membership in the Division I-A Big East Conference and academic decline, and opposition began to intensify and mobilize.

At this point in the book Dowling begins an intriguing narrative about the social movement designed to mobilize students, faculty, and alumni to stop Rutgers University from entering the world of big-time, commercialized intercollegiate sports. To Dowling's surprise it was several of his brightest and most capable students, 
strengthened by some faculty and alumni support, who first formally organized the social movement to fight against Division I-A athletics at Rutgers.

The first task undertaken by the group was the preparation of a petition to be published in the campus newspaper seeking student support for the withdrawal of Rutgers from the Big East Conference and Division I-A sports. The group took the name Rutgers 1000 (aka RU 1000) for this emerging social movement, with the idea that when one thousand signed petitions had been returned they would be presented to the Rutgers Board of Governors. This turned out to be more difficult than RU 1000 anticipated. The petition elicited only seven signatures from a student enrollment of over 20,000. Dowling's companion petition to the faculty was met with the same indifference.

Undaunted, RU 1000 set up a website for their campaign to make a case against commercialized Division I-A sports and rein in Rutgers athletics. The driving force and central communication component of RU 1000 for its nine years of activism was the "Web elves," as they were called. These were the students who kept the story of the social movement alive before a world-wide public audience on the Internet. They maintained contact with supporters, sought new members, replied to questions and criticisms, and kept records of events of all kinds that were related to the RU 1000 campaign. Dowling's account of the dedication, resourcefulness, ingenuity, and even humor of the RU 1000 web team will force readers to reconsider the low opinion some of them may have of college students. When they are dedicated to a meaningful cause, there is no limit to their capabilities. This is a theme that runs through the last seven chapters of this book.

While the Internet enabled RU 1000 to spread the word about their cause, it didn't provide the kind of "big-bang" dramatic spark that was necessary to thrust RU 1000 into the public consciousness of the entire Rutgers community-students, faculty, administration, governing board, and alumni. Several years into the RU 1000 campaign (by then expanded to include a Faculty Council and Alumni Council), that opportunity came through a remarkable set of circumstances, when a famous Rutgers alumnus (class of 1932), Milton Friedman-yes, THAT Milton Friedman - the Nobel laureate in economics, endorsed Rutgers 1000 in a statement published in the Daily Targum, the Rutgers campus newspaper. Significant as Friedman's endorsement was in building momentum and support for RU 1000, it still faced determined opposition from the hierarchy of power at Rutgers: the president, athletic director, Board of Governors, the Scarlet R boosters club, and even the New Jersey state legislature.

As Dowling's story of the activities of RU 1000 unfolds, he ruminates and writes about the mythology and hierarchies of power that are embedded in the structural interstices of all universities with big-time, commercialized intercollegiate sports. For him, the university administrations, coaches, athletic directors, booster clubs, governing boards, and state legislatures that control big-time, intercollegiate sports programs and perpetuate the hypocrisy, corruption, frequent scandals, and the enormous expenditures of money that permeate big-time college sports are collectively "empires of deceit."

Dowling is most alarmed about the effects on the social climate, campus intellectual culture, anti-academic mind-set, and quality of student applications and admissions of big-time sports universities throughout the nation. He articulately argues that professionalized commercial intercollegiate sports have a devastatingly 
anti-intellectual effect on these universities, but they are also detrimental to the status of higher education throughout the United States. He illustrates these effects by recounting the details of several college sports scandals at various universities (for example: recruiting, grade changing, and readmissions scandals at North Carolina State University during the tenure of Jim Valvano, and a grade-changing scandal at the University of Tennessee).

In 2002, after almost nine years of struggle, the RU 1000 social movement had not achieved its goal, and despite carrying out many noteworthy functions, which they called "symbolic interventions," the prospects for success looked grim. Then, much to their surprise and delight, the Rutgers president, Francis Lawrence, suddenly resigned. Although he had been a successful fund-raiser, he had been under fire throughout his tenure as president from a variety of groups and factions affiliated with Rutgers, not the least of which was RU 1000.

Celebrations followed for RU 1000 members, first over the resignation of a president who had been a gung-ho supporter of Division A-1 sports for Rutgers, second because the newly named president, Richard McCormick, had attended undergraduate and graduate colleges with participatory athletics, and he had once been the dean of arts and science at Rutgers. It was anticipated that he would withdraw Rutgers from big-time sports and return it to its core academic and intellectual values and its sports to a participatory athletics program. With the expectation that the new president would do that, RU 1000 disbanded in 2002.

Unfortunately, from Dowling's perspective, the thrill of victory soon turned to the agony of defeat for RU 1000. Shortly after taking over the Rutgers presidency, it became evident that Dr. McCormick intended to retain Rutgers membership in the Big East Conference and Division I-A sports. The details about this, and other issues surrounding McCormick's presidency_called McCormickgate-are best left to a full reading of the last chapter of the book.

So, despite the valiant efforts of Dowling, students, faculty, and alumni, the RU 1000 social movement lost its struggle. Its last act was to put up a website page that ended with these words: "Thus ended a luminous moment in Rutgers institutional history. Rutgers 1000. Requiescat in pace [Latin: rest in peace]." It may be accessed at http://members.aol.com/rutg1000

Confessions of a Spoilsport is a thought-provoking and superbly written work; indeed, Dowling's eloquent rhetoric is one of its strengths. Some readers of this book, however, will likely find Dowling's story unrepentantly self-righteous. Furthermore, his gratuitous condemnation and mockery of what he claims are the shoddy academic standards, anti-intellectual culture, and party-school atmosphere at many NCAA Division I-A universities will undoubtedly be resented by at least some students, faculty, and alumni associated with those institutions.

This is a book that would be appropriate reading for courses in sport studies, sport management, and higher education. It will surely stimulate lively class discussions. It is also a good read for a wider audience interested in issues of intercollegiate sports.

\section{References}

Freedman, S.G. (2007, September 26). "To the victors at Rutgers also goes the 'Spoilsport"” New York Times, p. B9. 


\section{Reclaiming the Game: College Sports and Educational Values}

By W.G. Bowen \& S.A. Levin. Published in 2005 by Princeton University Press, Princeton, NJ (496 pp., US \$25.95).

Reviewed by Packianathan Chelladurai, School of Physical Activity \& Educational Services, The Ohio State University, Columbus, Ohio.

William G. Bowen and Sarah A. Levin in collaboration with James L. Schulman, Colin C. Campbell, Susan C. Pichler, and Martin A. Kurzweil have written this sequel to an earlier book titled Game of Life by William G. Bowen and James L. Schulman. As the authors note, Reclaiming the Game was written to respond to the many questions stemming from the earlier book, particularly with reference to the conclusions: that athletes were treated preferentially in the admissions process, underperformed academically, and had a negative effect on campus life.

The later work is based on data from an impressive number of students $(27,811$ individuals) located at 33 schools belonging to the Ivy League, New England Small College Athletic Conference (NESCAC), and the University Athletic Association (UAA), as well as three women's colleges and seven coed-liberal arts colleges. Thus, the book is not about big-time intercollegiate athletics, in which one has come to expect scandals and other signs of wrongdoing. It is about the status of athletics in highly selective academic institutions. Bowen and Levin have lifted the veil to show that negative influences of intercollegiate athletics permeate even institutions known for their academics.

The book is organized in three parts. Part A is devoted to "Athletes on Campus Today" and describes the academic outcomes of athletes in high-profile sports (football, basketball, and hockey) and low-profile activities (the rest of the sports offered by the institutions). These chapters deal with recruiting practices, admission policies and procedures, academic credentials of the incoming athletes, the selection of academic fields of study, graduation rates and rank in class, and the underperformance of athletes. In Part B, while discussing the "Forces Creating the Athletic Divide," Bowen and Levin narrate the histories of the conferences, that is, how the athletic divide has widened over time, what forces within athletics led to the specialization of athletes in single sports and the professionalization of coaches, and finally, which elements of higher education contributed to this divide. In part C, Bowen and Levin take up "The Higher Ground: A Reform Agenda." They discuss the benefits of intercollegiate competition and the "costs" (mostly non-financial) of the academic-athletic divide, the ways in which the "recruiting-admissions-coaching nexus" can be changed to reduce the academic-athletic divide, the possibility of a new national structure within or outside the NCAA that would subscribe to and operate under the proposed reform agenda, and the processes of change needed to implement the new paradigm.

Bowen and Levin summarize very elegantly and concisely (pp. 327-331) their key findings, recommendations for reform, and ways of implementing those reforms. Their findings show that recruited athletes (i.e., those on coaches' lists presented to admissions' offices) had a significant admissions advantage over other students; athletes were concentrated in the fields of social science and business; they 
tended to band together thus creating a separate athletic culture; recruited athletes scored lower academically than walk-ons and other students; pressures from within and outside athletic and academic areas have led to increased specialization and intensity; and perhaps most importantly, athletes performed less well academically than their incoming credentials would predict.

Having noted the above problems, Bowen and Levin offer some recommendations for improvement. They include: reducing the number of recruited athletes and raising admission standards for them; increasing participation by walk-ons (those who were admitted on the basis of their academic credentials and not because of their athletic talent); hiring coaches for their overall performance as teachers and campus citizens; reducing the time commitment for varsity athletics; focusing on success during the regular season and within the local and regional levels; barring athletic scholarships and ensuring that need-based aid to athletes is legitimate; dropping football in some schools and limiting the squad size; holding competitions among schools of similar character; and creating a new national organizational structure (within the NCAA if possible) where the membership agrees to the principles implied by the above recommendations.

The authors direct our attention to some interesting but often overlooked details of athletics in the most selective institutions. The schools from which the data were gathered support, on average, more teams than Division I institutions. Further, the teams in these schools carry a larger number of athletes on their roster than a typical Division I school does. Thus, it is not surprising that athletes constitute 25 to $40 \%$ of the student population in Division III schools, whereas the percentage ranges from $20 \%$ to $30 \%$ in the Ivy League.

A notable feature of the study is the separation of recruited athletes from other athletes labeled walk-ons. This stratification allowed the authors to compare and contrast recruited athletes with all other athletes and regular students on academic performance before and after entry to a college or university.

The authors provide numerous quotations from insiders and experts to highlight significant points. In addition, the enormous data set was analyzed with appropriate statistical procedures, and the results were presented in the form of easy-to-read and easy-to-understand tables and charts. The findings substantiate the conclusions of the earlier book. Overall, Bowen and Levin have produced a monumental work rooted in convincing data that highlight certain tensions between academics and athletics. Scholars and practitioners reading this book would gain a great deal of insight on directions for future scholarly work and appropriate administrative practices. It is indeed a thought-provoking work. It has provoked this reviewer to advance the following ideas.

Whereas the findings reported in Reclaiming the Game cannot be questioned because they are based on a vast data set and sound statistical treatments, the implications drawn from those findings can. For instance, the overrepresentation of athletes in the fields of social science and business is supported by the data. But it is not clear how that becomes a measure of questionable academic performance. Would all students taking those courses be considered underperforming or otherwise deficient? In fact, attaching a stigma to those two fields is an affront to those disciplines, as well as the students and faculty associated with them.

On the issue of athletes banding together, Social Identity and Self-Categorization Theories would suggest that people tend to form groups based on a felt sense of 
similarity on any number of attributes. That would hold true for all students in any campus who form cliques based on perceived similarity. This is the case, for example, of the formally sanctioned professional fraternities that are established to serve the interests of the members of a particular profession. Thus, it would seem only reasonable that athletes who share the same ideology of pursuing excellence in sports, who undergo similar rigorous training, and have similar life-styles that suit their athletic commitments would tend to band together as a group. If engineering students can form fraternities and create their own culture, why shouldn't athletes bond together?

The authors the opportunity costs incurred when underperforming recruited athletes take seats from more academically qualified students. That is, the educational resources of the schools, in their view, are being spent on less deserving students. This assertion, however, needs to be tempered by the fact that although recruited athletes on average fared poorer academically than students-at-large, they apparently performed adequately enough to graduate. Such success, particularly among athletes coming from poor families or otherwise disadvantaged backgrounds, would seem to be consistent with the mission and purpose of most institutions.

Specialization of athletes in one sport and the professionalization/specialization of coaches are said by Bowen and Levin to be among the forces that ac-centuate the athletic-academic divide. Although the authors present data to support facts related to specialization and professionalization, it is not clear how these factors contribute uniquely to the academic-athletic divide. From a different perspective, it could be argued that specialization and professionalization are the routes to excellence in any field including sports. It is estimated that it would take 10,000 hours over 10 years for one to become an expert in a chosen activity (Ericsson, Krampe, \& TeschRömer, 1993). That process would require that an athlete or a coach specialize in one chosen sport and acquire high degrees of skill, knowledge, and competence in that activity. Even within one sport, there is a great tendency to specialize in one position (e.g., quarterback, running, and receiver in football; center, power forward, and point-guard in basketball). In the sport of volleyball, where the rules of the game require that every squad member rotate through the six positions on the court, players on high-level teams specialize only in two positions-one position in the front row and one position in the second row. Specialization, it would seem, is a requirement not only in sports but also in every sphere of life in which excellence is sought. It would be inconsistent to criticize specialization in sport when it is accepted in virtually every other walk of life.

Bowen and Levin's data clearly show that the major factor contributing to low academic performance is the admission of under-qualified athletes, and not the pressures and time demands of athletic training. The solution they advance is to restrict the number of recruits. Such a restriction would also serve the purpose of providing additional opportunities for more academically qualified walk-ons. Under this plan and with a reduction in the number of athletes that can be recruited, however, coaches are very likely to double their emphasis on athletic talent over academic potential. Limiting the number of athletes, therefore, is likely to expand the problem rather than curb it.

If recruitment is the root of all evil, as implied by the authors and their data, why not ban recruiting altogether? Such a step would allow high school athletes to select institutions that match their academic and athletic needs and interests. 
Everyone who plays on a university team would be a walk-on. Moreover, a ban on recruiting would save all the costs associated with it. Recently, the Chronicle of Higher Education (2008) reported that the cost of recruiting collegiate athletes has doubled between 1997 and 2007. According to the report, recruiting expenses in a single university could reach as high as $\$ 2$ million.

Keating (1964) distinguished between athletics, whose purpose is the pursuit of excellence, and sport, whose purpose is maximizing pleasure for contestants. These two spheres of activity are radically different enterprises that require different processes. Pursuit of excellence requires dedication, sacrifice, and intensity. As noted earlier, the development of expertise, as required in athletics, may require over 10,000 hours of focused training and practice. It also requires that the athletes demonstrate their excellence by competing against equally talented athletes in legitimate contests.

If athletics were to be accepted as full partners under the educational missions of colleges and universities, then we should facilitate educational-athletic process rather than curb it by placing restrictions on the length of seasons and practice sessions, and by restricting play-off and national championship experiences. We need to realize that excellence in sports can be pursued only when an individual is young, whereas academics can be pursued any time during one's life span. Further, these athletes "can achieve and demonstrate excellence and not just as apprentice learners but in performances that rank among the best at a high level of comparative judgment" (Simon, 2004, p. 160). Thus, athletics and academics as two elements of an overall education could be emphasized or de-emphasized in various combinations and within relatively liberal parameters. Instead of requiring athletes to take and pass a stipulated number of academic classes to remain eligible, it might make more sense to require all college or university students to make a certain amount of educational progress of whatever sort in order to remain in good standing at their respective institutions.

\section{References}

The Chronicle of Higher Education (2008). Hey, Big Spender. 7/28/2008 The Weekly Briefing from The Chronicle of Higher Education.

Ericsson, K.A., Krampe, R.T., \& Tesch-Römer, C. (1993). The role of deliberate practice in the acquisition of expert performance. Psychological Review, 103, 363-406.

Keating, J.W. (1964). Sportsmanship as a moral category. Ethics, 75, 25-35.

Simon, R. (2004). Fair play: The ethics of sport (2nd ed.). Boulder, Colorado: Westview. 